\title{
Leader-member exchange affects work engagement: The role of psychological well-being mediation
}

\author{
Winny Yus Permatasari, ${ }^{1}$ Fendy Suhariadi ${ }^{2}$ \\ ${ }^{1,2}$ Faculty of Psychology Universitas Airlangga, Surabaya - Indonesia
}

\begin{abstract}
Work engagement has a contribution to the success of an organization. Governmental institutions are often criticized for showing less satisfying performance and less effective services due to the misconducts of the civil servants such as coming late to work, leaving at working hours, and being less enthusiastic at work. This study aimed to examine civil servants' working conditions using three variables, namely leader-member exchange, psychological well-being, and work engagement. The measuring tools used referred to the Leader-Member Exchange Multidimensional (Liden \& Maslyn, 1998), Psychological Well-being Scale (Ryff, 1989) and Utrecht Work Engagement Scale (Schaufeli \& Bakker, 2004). There were 80 civil servants involved in this study as the subjects. They were selected using simple random sampling technique. Statistical techniques used in this study Structural Equation Modeling-Partial Least Square (SEM-PLS) with Warp PLS 5.0 Software. The result indicated that the three variables had a positive correlation with one another, and psychological well-being mediated the influence of leader-member exchange on work engagement.
\end{abstract}

Keywords: leader-member exchange; mediation; psychological well-being; work engagement; civil servants

\begin{abstract}
Abstrak: Work engagement berkontribusi dalam kesuksesan organisasi. Instansiinstansi pemerintahan sering dipandang memiliki kinerja kurang memuaskan dan pelayanan yang kurang efektif. Hal tersebut disebabkan perilaku menyimpang dari Aparatur Sipil Negara (ASN), seperti terlambat datang ke kantor, membolos dan mangkir saat jam kerja, dan tidak antusias dalam bekerja. Penelitian ini berupaya untuk mengkaji tentang kondisi kerja ASN dengan melibatkan tiga variabel, yaitu leader-member exchange (kualitas hubungan atasan-bawahan), psychological wellbeing (kesejahteraan psikologis), dan work engagement (keterikatan kerja). Alat ukur yang digunakan mengacu pada Leader-Member Exchange Multidimensional (Liden \& Maslyn, 1998), Psychological Well-Being Scale (Ryff, 1989), dan The Utrecht Work Engagement Scale (Schaufeli \& Bakker, 2004). Partisipan merupakan 80 orang ASN yang diperoleh melalui teknik simple random sampling. Teknik statistik yang digunakan adalah Structural Equation Modeling-Partial Least Square (SEM-PLS) dengan bantuan software WarpPLS versi 5.0. Diperoleh hasil bahwa seluruh variabel memiliki hubungan yang positif dan psychological well-being memberikan efek mediasi pada pengaruh leader-member exchange terhadap work engagement.
\end{abstract}

Kata Kunci: leader-member exchange; mediasi; psychological well-being; work engagement; Aparatur Sipil Negara

Corresponding Author: Winny Yus Permatasari (e-mail: yuswinny@gmail.com). Program Studi Magister Profesi Psikologi Fakultas Psikologi Universitas Airlangga. Jl. Airlangga No. 4-6, Surabaya, 60155. 


\section{Introduction}

Every organization needs to optimize its human resources (HR) as valuable assets in achieving its goals (Bakker \& Schaufeli, 2008). At work, every employee must have positive feelings and thoughts about his work. Employees who have positive feelings and thoughts are encouraged by having intrinsic motivation towards work, and this is one of the best assets of the organization (Sartono \& Ardhani, 2017). If employees have enthusiasm, are happy and feel an attachment to their work, then he will contribute with a good result for the organization (Kahn, 1990; Sarwar \& Aburge, 2013 cited by Abbas, 2017). Employees who have an attachment to their work are known as work engagement (WE), which are positive conditions that fulfill feelings and thoughts about work, shown through the existence of vigor, dedication, and absorption (Schaufeli, Salanova, González-romá, \& Bakker, 2002).

Willingness to devote themselves psychologically to work is the essence of WE (Schaufeli, 2013). Engagement is related to the level of attachment in work done by employees with positive feelings and thoughts to achieve organizational success (Schaufeli, Bakker, \& Salanova, 2006). Employees who are engaged will continue to enjoy their work, so they are encouraged to finish the job despite experiencing various kinds of difficulties. The more employees who have a strong work engagement, the more the organization will develop (Iswanto \& Agustina, 2016). However, according to the research of a metaanalysis that covered nearly 8,000 business units from 36 companies, only 35\% of organizations succeeded in creating WE (Evenson, 2014 cited by Hoole \& Bonnema, 2015). When compared to the private sector, engagement work on civil servants in the public sector is included in the low category and is often expressed as one of the reflections of organizations that have less optimal performance (Pritchard, 2008), such as agency X which is the object of this research. East Java Province that provides services includes the administrative process of determining promotions, transfers, pensions, civil servants' assignments that continue to their education and to attend training as well as staffing consultations.

WE on civil servants in Agency $\mathrm{X}$ are still not as expected as shown in the WE survey in 2018. Some behaviors that show problems regarding WE have been delayed by 443 times in the past month. There is also a postponement of the job, due to lack of enthusiasm in the work given, such as assuming work is less meaningful and ignoring work that is difficult to do and facing various problems encountered. Therefore, there are piles of files that should be able to be done quickly, but become ineffective, so that the impact on services is never on time. During working hours, several civil servants choose to spend their time in the cafeteria, chatting, and going out of the office for a long time even if it is not for work.

Referring to the Job Demands-Resources model, the level of WE are influenced by job demands and job resources. In several studies, job resources are the most likely factors to raise $\mathrm{WE}$ compared to job demands (Bakker \& Leiter, 2010; Mauno, Kinnunen, \& Ruokolainen, 2007). Job resources are physical, psychological, and social aspects of work. Social aspects include employee relations with colleagues, as well as relationships with superiors, also known as Leader-Member Exchange (LMX), LMX is a concept to explain the effect of effective leadership through group relationships (dyad) between superiors and subordinates (Dansereau, Graen, \& Haga, 1975). The difference between LMX and other leadership theories lies in the effectiveness of the quality of 
interactions between superiors and subordinates (Riggio, 2008) which emphasizes aspects of loyalty, affective, contribution, and professional respect (Liden \& Maslyn, 1998). The LMX theory shows that leader's develop unique relationships generated through a series of social exchanges that involve physical, mental, emotional support, and giving inf information, and trust that occurs between superiors and subordinates (Graen \& Uhl-Bien, 1995).

Based on survey data at Agency X, LMX is seen as a factor affecting, WE. As many as $94 \%$ of respondents agreed that the high or low subordinates engagement is influenced by the relationship with the chief leader, as interview supporting data also shows that the chief leader shows less attention, is less able to support what is needed related to work, and does not appreciate the competence of subordinates. Research stated that high-quality relationships with the leader will make subordinates more eager to dedicate themselves to work (Dhivya \& Sripirabaa, 2015; Gutermann, Lehmann-Willenbrock, Boer, Born, \& Voelpel, 2017).

Chief leaders who can provide the resources needed by subordinates to complete the work will make subordinates obliged to respond to these attitudes and behaviors with WE (Agarwal, Datta, Blake-Beard, \& Bhargava, 2012). Behavioral consequences of chief leader and subordinates can be explained through social exchange theory (SET) which is the most influential concept for understanding individual work behavior (Cropanzano \& Mitchell, 2005). In the SET context, individual behavior is determined by how reciprocal relationships occur with other people. Individuals obtain social exchanges that provide mutual benefits (Blau, 1964). Social exchange refers to reciprocal norms, when individuals behave well in other people, hence, at the same treatment will be received, so that social exchanges that occur become balanced in following reciprocity of what individuals do. Therefore, WE are a consequence of exchange from subordinates received from the leader. However, chief leaders are not always able to provide the resources which are needed by subordinates due to changes in the scope of work that makes superiors prioritize other things (Radstaak \& Hennes, 2017). In these conditions, subordinates need to be able to mobilize other resources they to have them to survive to face stressful work situations so that they remain engaged (Radstaak \& Hennes, 2017), one of which can be obtained from personal resources that encourage the creation of WE (Bakker \& Demerouti, 2008).

Personal resources are internal factors that function to support individual growth (Tesi, Aiello, \& Giannetti, 2018), in achieving work goals, controlling the environment, and overcoming potential situations that cause stress or threats (Hobfoll, Johnson, Ennis, \& Jackson, 2003; Ryff \& Singer, 2008).

Psychological well-being (PWB) as one of the personal resources becomes a source of special resilience (Tesi et al., 2018) and empowers employees to interact for stressful work activities (Ryff \& Singer, 2008). PWB becomes one of the personal resources that can act as a source of specific motivation (Gastañaduy, Herrera, \& Lens, 2014) which can influence employee behavior, influence the ability to make decisions, and influence employees in interacting with colleagues (Bandyopadhyay \& Srivastava, 2017). The existence of a high PWB will make employees able to see anything that happens as something positive even in difficult situations (Scheier, Carver, \& Bridges, 1994).

PWB is an actualization of the functioning of human potential as a whole (Deci \& Ryan, 2000; Snyder \& Lopez, 2002) in which is divided into 
environmental mastery, purpose in life, personal growth, autonomy positive relations with others, and self-acceptance (Ryff \& Keyes, 1995). PWB is closely related to WE because it focuses on the meaning of life which is manifested in terms of work activities (Ellis, 2016). When the employee can actualize his or her full potential, he or she will devote themselves happily to the job. The interaction between PWB and engagement leads to the formation of full engagement, such as when an individual has a high welfare condition, so, that individual will have high engagement (Robertson \& Cooper, 2009). The study stated that the stronger the PWB of employees, the stronger WE have (Vijayakumari \& Vrinda, 2016), so that ultimately it has an impact on optimal performance (Robertson \& Cooper, 2009; Wright \& Bonett, 2007).

There is also a relationship between LMX and PWB in several studies (Rodwell, Noblet, Demir, \& Steane, 2009; Trinchero, Borgonovi, \& FarrWharton, 2014; Sadida \& Fitria, 2019). Subordinates who have high LMX find it that they are accepted (Brouer \& Harris, 2007; Sparr \& Sonnentag, 2008 in Gregersen, Vincent-Höper, \& Nienhaus, 2016). Leaders who can provide attention, support and other resources that can support subordinates in working make subordinates feel valued, confident, and proud of the role of work performed (Cleland, Mitchinson \& Townend, 2008 in Messias, Mendes, \& Monteiro, 2010; Taghipour \& Dezfuli, 2013).

Therefore, it can be stated that organizations pay attention to employee welfare because employees spend most of their time working. When employees have good PWB quality, it will also have implications for the physical, psychological, and good behavior of employees (Maulida
\& Shaleh, 2017). It means the employee welfare has a positive effect on employee performance (Maulida \& Shaleh, 2017). Hence, when leaders and subordinates have a good relationship quality, subordinates will feel prosperous, so that it will have an impact on the performance of subordinates which will lead to good work engagement. Based on the description above regarding $\mathrm{LMX}, \mathrm{PWB}$, and $\mathrm{WE}$, it showed that the three variables have a positive correlation with each other. WE appear because of the LMX when individuals have the resources needed from leaders who can carry out their work so that individuals will reciprocate by working seriously and live up to their work role (WE).

Through LMX can bring PWB, when leaders can develop a good relationship by providing support, attention, and focus on the potential of subordinates, moreover, a trusting relationship is formed between the two. The consequences of this relationship make subordinates see themselves accepted, feel valuable, and meaningful with the work done.

PWB can bring up WE to provide resources from superiors and help subordinates to be able to actualize their full potential, there by generating positive feelings or thoughts that affect performance and appreciation of what is done. This will make individuals become attached to the job because there are more optimistic feelings, more confidence in completing work, and more resilient to challenges. So, the researchers set the hypothesis: There is an effect of leader-member exchange on work engagement by mediating psychological well-being in the civil servants at Agency X. The research model is shown in Figure 1. 


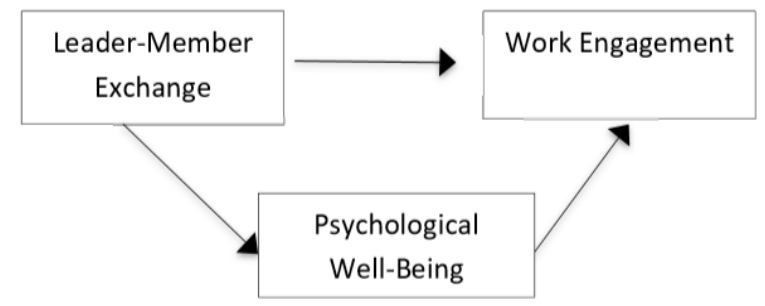

Figure 1. Research Model Relationship between LMX, PWB, and WE

The scopes of previous studies are mostly found in the settings of hospitals, educational institutions, industries, and non-profit organizations. So far, no research had been found that uses LMX as an independent variable, PWB as a mediator variable, and $\mathrm{WE}$ as the dependent variable in this study as used in the scope of government agencies. Therefore, this study is conducted to investigate which factors are more influential to improve WE so that civil servant's performance become more optimal in their job.

\section{Method}

This study used quantitative methods to examine the role of PWB meditation on the effect of LMX on WE. The population involved was civil servants from Agency $\mathrm{X}$, which focused on staffing the Government in East Java Provincial. The civil servants studied were at the structural, implementing and functional level. The dominant participants were male civil servants (62.03\%), civil servants aged $31-40$ years $(40.50 \%)$, civil servants with an undergraduate level of education (55.69\%), at the executive level (68.35\%), and civil servants with a working period of 11-15 years (37.97\%).

Determination of the number of samples from the population refers to the Krecjie table (Krejcie \& Morgan, 1970). If the population is 100 people and refers to the error level of $5 \%$, so, the sample used is 80 people. Simple random sampling technique is used with the consi- deration that all civil servants are possible to become participants.

The measurement of LMX which is using Leader-Member Multi-dimensional Exchange (LMX-MDM) based on Liden \& Maslyn, (1998) with a total of 12 items. The PWB variable was measured through the Psychological Well-Being Scale (PWBS) which refers to Ryff (1989) with a total of 18 items. The WE variable uses The Utrecht Work Engagement Scale (UWES) which refers to Schaufeli and Bakker (2003) with a total of 17 items.

All measuring instruments used have been adapted to a series of procedures: 1) reading original scale items in English, 2) translating them into Indonesian, 3) the result of the Indonesian translation is translated back into English (backtranslated). Adaptation process examined by 3 professional judgments who are competent in their fields, both those who work as lecturers and practitioners who have been in the HR field for more than 8 years. Besides having a role in checking the result of the translation of items, the professional judgment also checks all items to fit the research context and obtain valid items.

The questionnaire uses with Likert scale in five answer choices, such as Strongly Disagree, Disagree, Neutral, Agree, and Strongly Agree. The questionnaire is divided into a favorable statement for all items on the LMX-MDM and UWES scale. There are both favorable and unfavorable statements on the PWBS scale. Examples of favor- 
able items on the professional respect dimension in LMX-MDM such as: "I respect my leader's work competence" and favorable items on the dedication dimension in UWES such as: "I am always diligent in working". Examples of favorable items on the self-acceptance dimension in PWBS such as: "I feel satisfied with everything that happens in life" and unfavorable items on the environmental mastery dimension such as: "Demands in life often make me feel sad".

Measuring instrument tests were conducted on 39 samples that had similar characteristics to civil servants at Agency X. Based on reliability test, the LMX-MDM scale had a reliability of 0.945 , PWBS of 0.718, and UWES of 0.893. Reference criteria have been set by Sunjoyo (2013) that a good reliability value is $>0.6$ so that the three measuring devices are reliable. It is also known that all items in the three measuring instruments have a total item correlation $>0.2$ which means it is valid, according to the criteria determined by Nisfiannoor (2009) that an item is considered valid and is suitable for use if it has Total item correlation coefficient $>0.2$. Moreover, the three measuring instruments can be used as research data collection instruments.

Statistical techniques for analyzing data using Structural Equation Modeling-Partial Least Square (SEM-PLS) which is used of WarpPLS Software version 5.0, because of the compatibility with the characteristics of the study, especially the model can be estimated using a small number of sample sizes and does not have a requirement whether data distribution is normal or not, thus this model is non-parametric and can be applied to all types of scales (Sholihin \& Ratmono, 2014).

\section{Result}

Table 1 showed that there is no correlation between age and echelon of WE because the two demographic variables are not significant $(p>$
0.05). Meanwhile, tenure and education level correlates WE. The work period has a non-direct (negative) and a significant correlation to WE. That is, the longer the working period, the lower WE. This result is because civil servants who have worked for a long time in Agency X have experienced a decrease in motivation caused by the type of work that tends to be administrative. Civil servants are already familiar with these types of work, showed that work becomes a less challenging routine. When civil servants feel that their work is less challenging, attachment is low. This happens because WE emerge from an individual's view that work must be challenging and enjoyable (Schaufeli, 2012). Moreover, when civil servants view work as routine, it can lead to boredom so that work engagement is low (Robinson, Perryman, \& Hayday, 2004).

The result of this study is consistent with Kong's research (2009) which stated that employees with relatively long work periods can reduce their attachment to work. When compared to employees with relatively short work periods, the employee will feel more attached to work. That is because the work undertaken is still relatively new, therefore making employees with relatively short years of work feel fresh and full of energy, which makes them feel that the work provides something fun and challenging themselves. These feelings will direct employees towards genuine behavior of work. Table 1 also showed the level of education correlates $\mathrm{WE}$, meaning that the higher the level of education, the more engaged civil servants. This result is due to civil servants who have a high level of education will feel able to master both simple and complex work, so that it will lead to better work engagement. The result of this study is supported by research that found in education level is related to WE (Sharma, Goel, \& Sengupta, 2017). 
Table 1.

Result of Variable Demographic Analysis

\begin{tabular}{ccc}
\hline & Score Work Engagement & \\
\hline Explanation & $r$ (correlation coefficient) & $\mathrm{p}$ (significance) \\
Age & 0.196 & 0.084 \\
Years of service & -0.231 & 0.04 \\
Echelon & 0.163 & 0.151 \\
Level of education & $($ significant at $\mathrm{p}<0.05)$ & 0.001 \\
& 0.355 & \\
\hline
\end{tabular}

\section{Evaluation of the Outer Model}

Data analysis refers to the second-order construct confirmatory factor analysis, indeed the three variables used are multidimensional constructs. In evaluating the outer model, it is necessary to examine convergent validity, which aims to measure the magnitude of the correlation between dimensions with latent variables. Item is considered valid if it has a loading value $>0.7$ and a significant p-value $<0.05$ (Sholihin \& Ratmono, 2014). Indicators with loading values $<0.7$ must be removed from the model. However, if the average variances extracted (AVE) is already $>0.5$ and has a composite reliability> 0.7 (Sholihin \&
Ratmono, 2014), so, indicators with loading values ranging from 0.4-0.7 can still be included in this model. Based on the analysis conducted, all LMX variable indicators have fulfilled the convergent validity requirements, as in Table 2.

In contrast to some indicators of the PWB and WE variables which have AVE <0.5. Invalid indicators are PWB1 and PWB13. PWB5 and PWB17 indicators are still maintained, because the indicator values in each dimension already have AVE values> 0.5 and composite reliability> 0.7 , as in table 3 .

Table 2.

Loading Factor LMX

\begin{tabular}{ccccc}
\hline Item & Dimension & Loading Factor & Value $p$ & Explanation \\
\hline LMXS1 & Affect & 0.907 & $<0.001$ & Valid \\
LMXS2 & & 0.936 & $<0.001$ & Valid \\
LMXS3 & & 0.951 & $<0.001$ & Valid \\
LMXS4 & Loyalty & 0.826 & $<0.001$ & Valid \\
LMXS5 & & 0.936 & $<0.001$ & Valid \\
LMXS6 & & 0.944 & $<0.001$ & Valid \\
LMXS7 & Contribution & 0.766 & $<0.001$ & Valid \\
LMXS8 & & 0.881 & $<0.001$ & Valid \\
LMXS9 & & 0.880 & $<0.001$ & Valid \\
LMXS10 & Professional & 0.921 & $<0.001$ & Valid \\
LMXS11 & Respect & 0.912 & $<0.001$ & Valid \\
LMXS12 & & 0.966 & $<0.001$ & Valid \\
\hline
\end{tabular}


Table 3.

PWB Loading Factor

\begin{tabular}{ccccc}
\hline Item & Dimension & Loading Factor & Valu- $p$ & Explanation \\
\hline PWB1 & Autonomy & 0.322 & 0.001 & Invalid \\
PWB2 & & 0.843 & $<0.001$ & Valid \\
PWB3 & & 0.845 & $<0.001$ & Valid \\
PWB4 & Environmental Mastery & 0.742 & $<0.001$ & Valid \\
PWB5 & & 0.563 & $<0.001$ & Valid \\
PWB6 & & 0.793 & $<0.001$ & Valid \\
PWB7 & Personal Growth & 0.745 & $<0.001$ & Valid \\
PWB8 & & 0.884 & $<0.001$ & Valid \\
PWB9 & & 0.740 & $<0.001$ & Valid \\
PWB10 & Positive Relation with & 0.790 & $<0.001$ & Valid \\
PWB11 & Others & 0.706 & $<0.001$ & Valid \\
PWB12 & & 0.709 & $<0.001$ & Valid \\
PWB13 & Purpose in Life & -0.514 & $<0.001$ & Invalid \\
PWB14 & & 0.762 & $<0.001$ & Valid \\
PWB15 & & 0.766 & $<0.001$ & Valid \\
PWB16 & Self-Acceptance & 0.902 & $<0.001$ & Valid \\
PWB17 & & 0.471 & $<0.001$ & Valid \\
PWB18 & & 0.829 & $<0.001$ & Valid \\
\hline
\end{tabular}

Table 4.

WE Loading Factor

\begin{tabular}{|c|c|c|c|c|}
\hline Item & Dimensi & Loading Factor & Value- $p$ & Keterangan \\
\hline WE1 & \multirow[t]{6}{*}{ Vigour } & 0.865 & $<0.001$ & Valid \\
\hline WE2 & & 0.906 & $<0.001$ & Valid \\
\hline WE3 & & 0.873 & $<0.001$ & Valid \\
\hline WE4 & & 0.446 & $<0.001$ & Valid \\
\hline WE5 & & 0.444 & $<0.001$ & Valid \\
\hline WE6 & & 0.774 & $<0.001$ & Valid \\
\hline WE7 & \multirow[t]{5}{*}{ Dedication } & 0.869 & $<0.001$ & Valid \\
\hline WE8 & & 0.753 & $<0.001$ & Valid \\
\hline WE9 & & 0.867 & $<0.001$ & Valid \\
\hline WE10 & & 0.821 & $<0.001$ & Valid \\
\hline WE11 & & 0.666 & $<0.001$ & Valid \\
\hline WE12 & \multirow[t]{6}{*}{ Absorption } & 0.599 & $<0.001$ & Valid \\
\hline WE13 & & 0.270 & 0.005 & Invalid \\
\hline WE14 & & 0.676 & $<0.001$ & Valid \\
\hline WE15 & & 0.852 & $<0.001$ & Valid \\
\hline WE16 & & 0.813 & $<0.001$ & Valid \\
\hline WE17 & & 0.557 & $<0.001$ & Valid \\
\hline
\end{tabular}

The WE indicator that must be removed because it does not meet the convergent validity requirements is WE13. The indicators WE4, WE5,
WE11, WE12, WE14, and WE17 are still maintained, because each of these dimensions has 
a value of AVE $>0.5$ and composite reliability $>0.7$, as in Table 4.

After deleting the indicator, changes in the AVE and Cronbach's Alpha values occur. The result obtained is that all PWB and WE indicators are valid, showing the composite reliability and AVE values in Table 5.

Table 5 showed the composite reliability, Cronbach's Alpha, and AVE values after entering the three latent variables. According to Sholihin \& Ratmono (2014), indicator requirements are declared valid if they have composite reliability values $>0.7$, Cronbach alpha $>0.6$, and AVE values $>0.5$. Therefore, the LMX, PWB, and WE variables are said to be valid, if they meet the recommended conditions. Even though the AVE value of $\mathrm{PWB}$ is $<0.5$, it has composite reliability $>$ 0.6 , so that the construct is still declared valid (Fornell \& Larcker, 1981)..

The second step after measuring the inner model is the outer model. This is done to show the correlation between indicators with all latent variables. Then it is done by showing a crossloading measurement with its construct. The indicator is declared valid if it has the highest loading factor in the construct measured compared to the loading factor of other constructs. Based on the results of the study, discriminant validity has been fulfilled because all indicators of latent variables are valid.

Cronbach's Alpha value and composite reliability on a variable can indicate internal consistency reliability on a variable (Ringle, Sarstedt, \& Straub, 2012). Cronbach Alpha value and composite reliability are quantities that indicate the size of the consistency and reliability of a measuring instrument. It is declared reliable if the value of Cronbach alpha $>0.6$ and composite reliability $>$ 0.7. After having done the calculation, the composite reliability values of LMX (0.930), PWB (0.779), and WE (0.922). LMX has a Cronbach alpha (0.899), PWB (0.659), and WE $(0.874)$ values. This result meets the standards in which is meant the three variables are reliable.

\section{Evaluation of Inner Model}

The structural model refers to the magnitude of R2 which is a reflection of the presentation of variance in latent variables that are thought to be the cause (Kock, 2013). There is Q2 in the evaluation of structural models that indicate the level of predictive relevance of the research model (Ghozali \& Latan, 2014) with a criterion of Q2 value $<0$, it means that the model lacks predictive relevance (Ghozali \& Latan, 2014). Evaluate structural models as in table 6 .

In Table 6, the value of 0.493 for the WE variable showed that LMX and PWB can explain the WE variable by $49.3 \%$, the remaining $50.7 \%$ is explained by factors not used in the model. PWB has an R2 value of 0.134 , meaning that the PWB variance can be explained by LMX by $13.4 \%$, while the remaining $86.6 \%$ is explained by other factors involved in the model. Referring to this result, it can be interpreted that there are still other factors outside the model that can affect WE in the public sector. The result of the Q2 calculation in this study showed that the Q2 values owned by the endogenous variables PWB and WE are above $0(\mathrm{Q} 2>0)$, which means that exogenous variables have a good predictive relevance ability towards endogenous variables. LMX becomes an exogenous variable that can predict $\mathrm{PWB}$ and $\mathrm{WE}$ as its endogenous variables. Next, it tests the model fit, which refers to 4 criteria for model fit, such as Average R-Square (ARS), Average Adjusted R-Squared (AARS), Average Path Coefficient (APC), and Average Block Variant Inflation Factor (APC) AVIF). 
Table 5.

Coefficient of Latent Variables after Elimination

\begin{tabular}{cccc}
\hline & LMX & PWB & WE \\
Composite Reliability & 0.930 & 0.779 & 0.922 \\
Cronbach Alpha & 0.899 & 0.659 & 0.874 \\
Average Variances Extracted (AVE) & 0.771 & 0.378 & 0.799
\end{tabular}

Table 6.

Evaluation of Structural Model

\begin{tabular}{ccc}
\hline \multirow{2}{*}{ Explanation } & \multicolumn{2}{c}{ Variabel Endogen } \\
& Psychological Well-Being & Work Engagement \\
\hline R-Square Coefficients & 0.134 & 0.493 \\
Q-Square Coefficients & 0.123 & 0.480 \\
\hline
\end{tabular}

Table 7.

Result of Fit Model

\begin{tabular}{cccc}
\hline ARS & AARS & APC & AVIF \\
$0.314, \mathrm{P}<0.001$ & $0.301, \mathrm{P}<0.001$ & $0.415, \mathrm{P}<0.001$ & 1.047 \\
\hline
\end{tabular}

Table 8.

Summary of Hypothesis Test Result

$\begin{array}{ccc}\text { Indirect Influence } & \beta & \text { P values } \\ \text { LMX }>\text { WE } & 0.57 & <0.01 \\ \text { LMX }>\text { PWB } & 0.37 & <0.01 \\ \text { PWB }->\text { WE } & 0.31 & <0.01 \\ \text { Direct Influence } & \beta & \text { P values } \\ \text { LMX }>\text { WE } & 0.63 & <0.01 \\ \text { LMX }->\text { PWB } & 0.37 & <0.01 \\ \text { PWB }->\text { WE } & 0.43 & <0.01\end{array}$

The size of the fit model refers to the $p$-value $\leq 0.05$. The AVIF model criteria are used to show the problem of colinearity in the PLS model, where the recommended value is $\leq 3.3$ (Ghozali \& Latan, 2014).

The result of the model fit in table 7 showed that the model complies with the criteria. ARS, AARS, and APC have a significance value of $\mathrm{p} \leq 0.05$. AVIF value of 1,047 indicated that the value is less than the ideal threshold of 3.3 which indicates that the model does not have multicollinearity problems.

\section{Hypothesis test}

The set of hypothesis test can be shown from the result of the estimated coefficient of determination (R2) with the value of the beta coefficient ( $\beta$ ) and $p$-value. The $\beta$ value has value by the direction of the hypothesis relationship and the p-value $<5 \%$. The estimation results can be shown in Figure 2. 


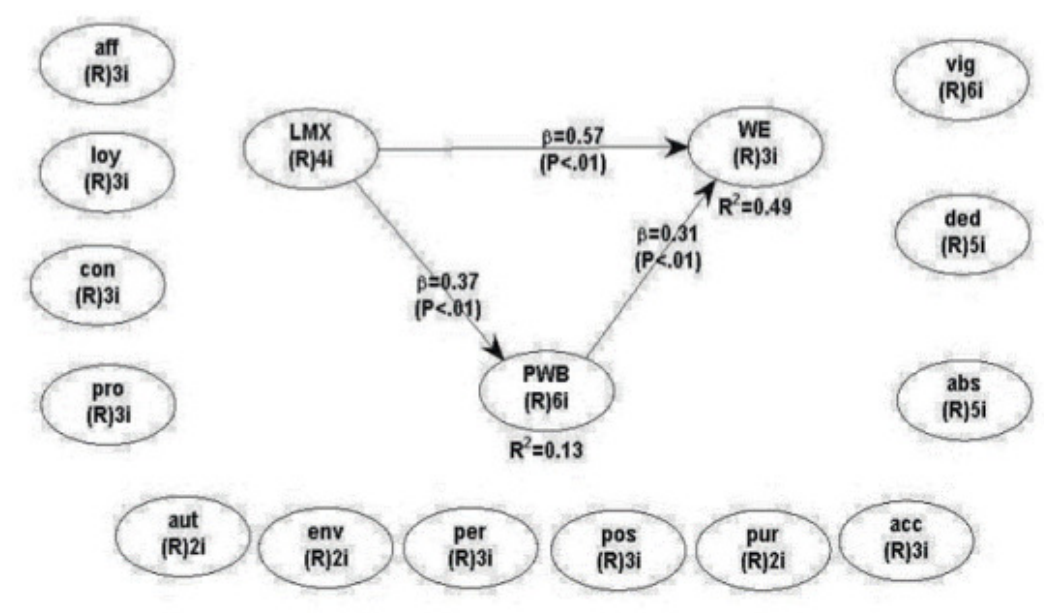

Figure 2. The indirect effect of Leader-Member Exchange on Work Engagement with Psychological Well-Being Mediation

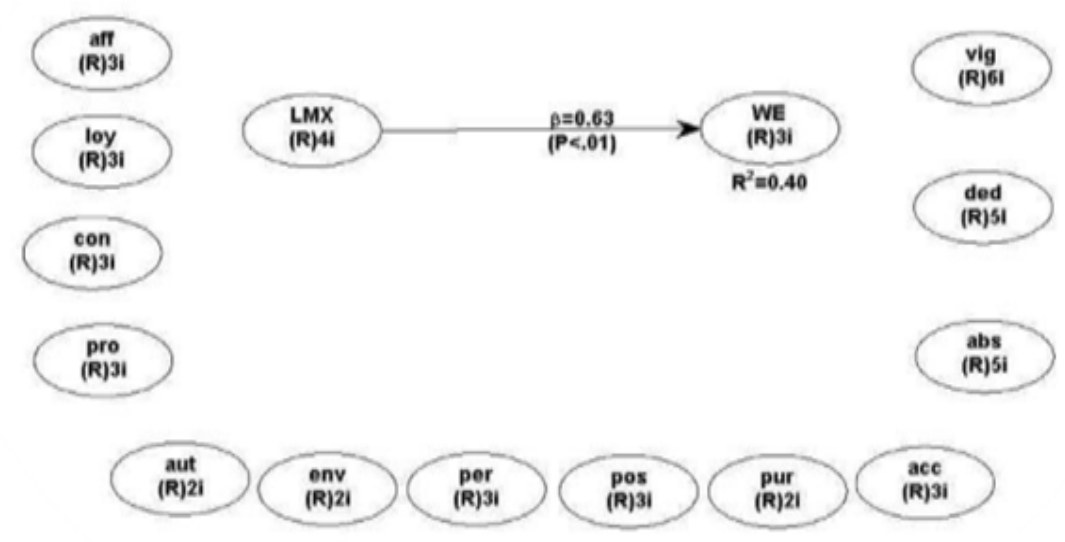

Figure 3. Direct Effect of Leader-Member Exchange on Work Engagement

Figure 2 showed that the effect of LMX on PWB has a $\beta$ value of 0.37 and a significant $p$ value $(0.01<0.05)$, the effect of PWB on WE have a $\beta$ value of 0.31 and a significant $p$-value $(0.01$ $<0.05)$. The effect of LMX on WE have a $\beta$ value of 0.57 and a significant $p$-value $(0.01<0.05)$. The $p$ value remained significant $(<0.01)$ on the effect of LMX on WE after the PWB variable was entered and showed that PWB partially mediated the effect of LMX on WE. Hence, the hypothesis is stated that the influence of leader-member exchange on work engagement by mediating psychological well-being in the civil servants in Agency X is accepted.

\section{Discussion}

This study aims to examine the role of PWB on the effect of LMX on WE in Agency X. Based on table 8 , the research model between the three variables showed significant result. Table 8 also explained the direct effect of LMX on WE and the indirect effect of LMX on WE with PWB mediation. Referring to the result that has been obtained, it can be concluded that PWB partially 
mediates the influence between LMX on WE, so that in this study the hypothesis is accepted.

This research model uses three variables that have not been found in previous research models, with the use of PWB as a mediator, so the result of the study will focus on previous research models that examine the effect of LMX on WE, the effect of LMX on PWB, and the effect of PWB on WE. The result in this study is in line with research by Dhivya and Sripirabaa (2015), Gutermann et al. (2017) and Wulandari and Ratnaningsih (2016) who discovered the effect of LMX on WE. This study also showed that LMX influences PWB, in line with research by Burnette (2012) and Trinchero et al. (2014). This study also proved the influence of PWB on WE, which is in line with research by Marques (2013), Vijayakumari and Vrinda (2016), and Tesi et al. (2018) who found the influence of PWB on WE.

In connection with the problem of working conditions in civil servants in Agency $\mathrm{X}$ that have been explained in the background of the study, the lack of support, attention, and appreciation given by the leader to subordinates is believed to be one of the factors that influence WE. Therefore, the quality of the relationship between the leaders and subordinates needs to be strengthened, so that both will receive social exchanges that lead to the emergence of work engagement. When the leaders show support, attention, provide opportunities for growth, fair supervision, meaningfulness of work, and autonomy, then these resources can be responded to as beneficial to subordinates, then subordinates will feel obliged to reciprocate by investing themselves fully in work (Liden, Sparrowe, \& Wayne, 1997; Sparr \& Sonnentag, 2008). The focus on providing support to one another relates to the dimension of loyalty, which is believed to be an important factor in maintaining the quality of relations between leader and subordinates, therefore the dimension of loyalty plays an important role in LMX (Dienesch \& Liden, 1986).

Being a pleasant leader and being able to treat a subordinate like a friend will make a subordinate's presence acceptable and valued. The treatment of the leader to subordinates is related to the effect dimension, which also plays an important role in LMX (Liden, Wayne, \& Stilwell, 1993). The leaders who build close and intimate relationships with subordinates can stimulate the emergence of affective reactions during work (Kuvaas \& Dysvik, 2010). This may have implications for the emergence of good PWB so that it can also affect good performance in the workplace (Maulida \& Shaleh, 2017). Therefore, the relationship developed not only emphasizes the formal aspects of work but also focuses on interpersonal relationships by showing behaviors that can make subordinates feel safe and comfortable so that a relationship of mutual trust is formed.

The existence of togetherness that produces trust and security is an essential basic human need for the achievement of PWB (Ryan \& Deci, 2001). The leaders contribute to the emergence of PWB when the leader can pay attention, support, and support subordinates at work (Messias, Mendes, \& Monteiro, 2010). Organizations need to pay attention to employee PWB to improve performance (Page \& Vella-Brodrick, 2009). The existence of PWB owned by employees will make individuals feel involved and motivated in work, and have positive energy and be able to enjoy work activities for a long time (Berger, 2010). The result indicated that employees will give more effort that is aligned with the goals of the organization when employees perceive the organization can appreciate the role and contribution and care for their psychological well-being (Byrne \& MacDonagh, 2018). Based on the 
conditions at Agency X, the result showed that there is a negative and significant correlation between years of service to WE. This means that the longer the civil servants' service life, the lower the WE. It can happen due to civil servants who tend to feel familiar with their work so that the work is viewed as a routine that does not provide fun and challenges (Kong, 2009). There is also a positive correlation between education level and WE. It can occur because civil servants who have relatively high levels of education feel able to master their work so that they are more enthusiastic, optimistic, and confident to complete the work (Avey et al., 2010 quoted from Robertson \& Cooper, 2009; Gregersen et al., 2016).

Referring to the result of several studies related to variables in this study, generally, there is the positive result between the effect of LMX on WE, the effect of LMX on PWB, and the effect of PWB on WE. Nevertheless, research conducted to examine the effect of LMX on WE with PWB mediation is still significantly limited, so the results of this study are expected to be able to provide references regarding LMX, PWB, and WE which are part of the realm of industrial and organizational psychology. This study is limited to the scope of the Government of the Province of East Java, so the result of the study cannot be generalized to other government agencies. It is due to differences in the characteristics of different civil servants, so the possibility of the result is also different. This study showed that there is an LMX effect on WE with PWB mediation. There are several items on PWB and WE that lead to social desirability, so individuals tend to show positive things or have the possibility of answering something with what is socially acceptable.

\section{Conclusion}

Based on the result of the study, it can be concluded that there is an effect of leader-member exchange on work engagement by mediating psychological well-being. The leaders who can develop good relations through providing support, attention and focus on the potential of subordinates will form a relationship of mutual trust. This makes the subordinate view that they are accepted, feels valuable, and proud of the work done so that it raises positive feelings or thoughts about the job. Subordinates become attached to the job, because of the feeling of being more optimistic, having more confidence to be able to finish the job and more resilient in facing challenges.

\section{Suggestion}

The suggestions that can be given to Agency X is to improve the quality of relations between leader and subordinates by applying to coach. Coaching aims to improve interpersonal relationships and the ability of individuals to achieve goals (Cummings \& Worley, 2009). Coaches who carry out the coaching process to subordinates will communicate more intensely, meaning that coaching can also be a means of communicating, so that they can form a better LMX. In the process of coaching, the leader can motivate subordinates related to difficulties encountered during work (Sarisusantini, 2012). The process can build trust from subordinates as a result of openness that is owned by subordinates when telling problems faced by the leader. The ability of the leader to help difficulties faced by subordinates will make subordinates view superiors as having the competencies expected of a leader so that the quality of the relationship between the two becomes better.] 


\section{References}

Abbas, M. (2017). The effect of organizational culture and leadership style towards employee engagement and their impact towards employee loyalty. Asian Journal of Technology and Management Research, 7(7), 1-11.

Agarwal, U. A., Datta, S., Blake-Beard, S., \& Bhargava, S. (2012). Linking LMX, innovative work behaviour and turnover intentions. Career Development International, 17(3), 208-230. https://doi.org/ $10.1108 / 13620431211241063$

Bakker, A. B., \& Demerouti, E. (2008). Towards a model of work engagement. Career Development International, 13(3), 209-223. https://doi.org/10.1108/13620430810870476

Bakker, A. B., \& Leiter, M. P. (Eds.). (2010). Work engagement: A handbook of essential theory and research. New York: Psychology Press.

Bakker, A. B., \& Schaufeli, W. B. (2008, February). Positive organizational behavior: Engaged employees in flourishing organizations. Journal of Organizational Behavior, Vol. 29, pp. 147-154. https://doi.org/10.1002/job.515

Bandyopadhyay, G., \& Srivastava, K. B. L. (2017). Determinants of psychological well-being and its impact on mental health and employee engagement. Indian Journal of Health and Well-Being, 8(4), 250257. Retrieved from https://www.researchgate.net/publication/317302790_Determinants_ of_psychological_well-being_and_its_impact_on_mental_health_and_employee_engagement

Berger, A. (2010). Review: Happiness at work. USA: Basil \& Spice.

Blau, P. M. (1964). Exchange and power in social life. New York: Wiley.

Burnette, C. M. (2012). How leadership can influence well-being: The roles ofleader-member exchange and social support. University of Clemson.

Byrne, O., \& MacDonagh, J. (2018). What's love got to do with it? Employee engagement amongst higher education workers. The Irish Journal of Management, 36(3), 189-205. https://doi.org/ 10.1515/ijm-2017-0019

Cropanzano, R., \& Mitchell, M. S. (2005). Social exchange theory: An interdisciplinary review. Journal of Management, 31(6), 874-900.

Cummings, T. G., \& Worley, C. G. (2009). Organization development \& change (J. W. Calhoun \& M. Acuña, Eds.). Retrieved from www.ichapters.com

Dansereau, F., Graen, G., \& Haga, W. J. (1975). A vertical dyad linkage approach to leadership within formal organizations. A longitudinal investigation of the role making process. Organizational Behavior and Human Performance, 13(1), 46-78. https://doi.org/10.1016/00305073(75) $90005-7$

Deci, E. L., \& Ryan, R. M. (2000). The "what" and "why" of goal pursuits: Human needs and the selfdetermination of behavior. Psychological Inquiry, 11(4), 227-268. https://doi.org/ 10.1207/S15327965PLI1104_01

Dhivya, A. S., \& Sripirabaa, B. (2015). The impact of leader member exchange on work engagement: An empirical study. International Journal of Management (IJM), 6(1), 139-150. Retrieved from http://www.iaeme.com/IJM.asp 
Dienesch, R. M., \& Liden, R. C. (1986). Leader-Member Exchange model of leadership: A critique and further development. The Academy of Management Review, 11(3), 618-634. https://doi.org/ $10.2307 / 258314$

Fornell, C., \& Larcker, D. F. (1981). Evaluating structural equation models with unobservable variables and measurement error. Journal of Marketing Research, (1), 39. https://doi.org/ $10.2307 / 3151312$

Gastañaduy, K., Herrera, D., \& Lens, W. (2014). Work motivation and psychological well-being of volunteers and non-volunteers. Revista de Orientación Educacional, 28(53), 37-50. Retrieved from https://www.semanticscholar.org/paper/Work-motivation-and-psychological-wellbeing-of-and-Gastañaduy-Herrera/3fa685d78b8854c9058157a44394afdf6caf9a9c

Ghozali, I., \& Latan, H. (2014). Partial Least Squares: Konsep, teknik dan aplikasi menggunakan program SmartPLS3.O. Semarang: Penerbit Universitas Diponegoro.

Graen, G. B., \& Uhl-Bien, M. (1995). Relationship-based approach to leadership: Development of leadermember exchange (LMX) theory of leadership over 25 years: Applying a multi-level multidomain perspective. The Leadership Quarterly, 6(2), 219-247. https://doi.org/10.1016/10489843(95)90036-5

Gregersen, S., Vincent-Höper, S., \& Nienhaus, A. (2016). Job-related resources, leader-member exchange and well-being-a longitudinal study. Work and Stress: An International Journal of Work, Health \& Organisations, 30(4), 356-373. https://doi.org/10.1080/02678373.2016.1249440

Gutermann, D., Lehmann-Willenbrock, N., Boer, D., Born, M., \& Voelpel, S. C. (2017). How leaders affect followers' work engagement and performance: Integrating leader-member exchange and crossover theory. British Journal of Management, 28(2), 299-314. https://doi.org/ 10.1111/1467-8551.12214

Hobfoll, S. E., Johnson, R. J., Ennis, N., \& Jackson, A. P. (2003). Resource loss, resource gain, and emotional outcomes among inner city women. Journal of Personality and Social Psychology, 84(3), 632643. https://doi.org/10.1037/0022-3514.84.3.632

Hoole, C., \& Bonnema, J. (2015). Work engagement and meaningful work across generational cohorts. SA Journal of Human Resource Management, 13(1), 1-11. https://doi.org/10.4102/ sajhrm.v13i1.681

Iswanto, F., \& Agustina, I. (2016). Peran dukungan sosial di tempat kerja terhadap keterikatan kerja karyawan. Mediapsi, 02(02), 38-45. https://doi.org/10.21776/ub.mps.2016.002.02.6

Kahn, W. A. (1990). Psychological conditions of personal engagement and disengagement at work. Academy of Management Journal, 33(4), 692-724. https://doi.org/10.2307/256287

Kock, N. (2013). WarpPLS 4.0 User Manual. Laredo Texas: ScriptWarp Systems.

Kong, Y. (2009). A study on the job engagement of company employees. International Journal of Psychological Studies, 1(2), 65-68. https://doi.org/10.5539/ijps.v1n2p65

Kuvaas, B., \& Dysvik, A. (2010). Exploring alternative relationships between perceived investment in employee development, perceived supervisor support and employee outcomes. Human Resource Management Journal, 20(2), 138-156. https://doi.org/10.1111/j.17488583.2009.00120.x

Liden, R. C., \& Maslyn, J. M. (1998). Multidimensionality of leader-member exchange: An empirical assessment through scale development. Journal of Management, 24(1), 43-72. https://doi.org/ $10.1177 / 014920639802400105$ 
Liden, R. C., Sparrowe, R. T., \& Wayne, S. J. (1997). Leader-member exchange theory: The past and potential for the future. In G. R. Ferris (Ed.), Research in Personnel and Human Resources Management (Vol. 15, pp. 47-119). US: Elsevier Science/JAI Press.

Liden, R. C., Wayne, S. J., \& Stilwell, D. (1993). A longitudinal study on the early development of leadermember exchanges. Journal of Applied Psychology, 78(4), 662-674. https://doi.org/ 10.1037/0021-9010.78.4.662

Marques, R. A. (2013). Antecedents and uutcomes of work-related psychological well-being of staff members of The University of Namibia. The University of Namibia, Namibia.

Maulida, D., \& Shaleh, A. R. (2017). Pengaruh Modal Psikologis dan Totalitas Kerja terhadap Kesejahteraan Subjektif. Psikohumaniora: Jurnal Penelitian Psikologi, 2(2), 107-124. https://doi.org/10.21580/pjpp.v2i2.2461

Mauno, S., Kinnunen, U., \& Ruokolainen, M. (2007). Job demands and resources as antecedents of work engagement: A longitudinal study. Journal of Vocational Behavior, 70(1), 149-171. https://doi.org/10.1016/j.jvb.2006.09.002

Messias, F., Mendes, J., \& Monteiro, I. (2010). The effects of leadership behaviors on the employee wellbeing in the workplace: a worthy investment from managers or leaders.

Nisfiannoor, M. (2009). Pendekatan statistika modern untuk ilmu sosial. Jakarta: Salemba Humanika.

Page, K. M., \& Vella-Brodrick, D. A. (2009). The "what", "why" and "how" of employee well-being: A new model. Social Indicators Research, 90(3), 441-458. https://doi.org/10.1007/s11205-0089270-3

Pritchard, K. (2008). Employee engagement in the UK: Meeting the challenge in the public sector. Development and Learning in Organisations, 22(6), 15-17. https://doi.org/10.1108/ 14777280810910302

Radstaak, M., \& Hennes, A. (2017). Leader-member exchange fosters work engagement: The mediating role of job crafting. SA Journal of Industrial Psychology, 43(0). https://doi.org/ 10.4102/sajip.v43i0.1458

Riggio, R. E. (2008). Leadership development: The current state and future expectations. Consulting Psychology Journal, 60(4), 383-392. https://doi.org/10.1037/1065-9293.60.4.383

Ringle, C. M., Sarstedt, M., \& Straub, D. W. (2012). Editor's Comments: A critical look at the use of PLSSEM in MIS Quarterly. MIS Quarterly: Management Information Systems, Vol. 36, pp. iii-xiv. https://doi.org/10.2307/41410402

Robertson, I. T., \& Cooper, C. L. (2009). Full engagement: The integration of employee engagement and psychological well-being. Leadership \& Organization Development Journal, 31(4), 324-336. https://doi.org/10.1108/01437731011043348

Robinson, D., Perryman, S., \& Hayday, S. (2004). The drivers of employee engagement. Report-Institute for Employment Studies.

Rodwell, J., Noblet, A., Demir, D., \& Steane, P. (2009). Supervisors are central to work characteristics affecting nurse outcomes. Journal of Nursing Scholarship: An Official Publication of Sigma Theta Tau International Honor Society of Nursing, 41(3), 310-319. https://doi.org/10.1111/j.15475069.2009.01285.x

Ryan, R. M., \& Deci, E. L. (2001). On happiness and human potentials: A review of research on hedonic and eudaimonic well-being. Annual Review of Psychology, 52(1), 141-166. https://doi.org/ 10.1146/annurev.psych.52.1.141 
Ryff, C. D. (1989). Happiness is everything, or is it? Explorations on the meaning of psychological wellbeing. Journal of Personality and Social Psychology, 57(6), 1069-1081. https://doi.org/ 10.1037/0022-3514.57.6.1069

Ryff, C. D., \& Keyes, C. L. M. (1995). The Structure of Psychological Well-Being Revisited. 69(4), 719-727.

Ryff, C. D., \& Singer, B. H. (2008). Know thyself and become what you are: a eudaimonic approach to psychological well-being. 13-39. https://doi.org/10.1007/s10902-006-9019-0

Sadida, N., \& Fitria, N. (2019). Analisis kesejahteraan psikologis karyawan dan kualitas interaksi bawahan berdasarkan kepribadian atasan. Humanitas, 15(1), 72-81. https://doi.org/ 10.26555/humanitas.v15i1.5328

Sarisusantini, K. (2012). Meningkatkan leader member exchange dari bawahan dan kepuasan terhadap atasan melalui pelatihan coaching bagi penyelia di PT X. Universitas Indonesia.

Sartono, H., \& Ardhani, M. (2017). Work engagement, intrinsic motivation and job satisfaction among employees of a coal mining company in South Borneo. International Research Journal of Business Studies, 8(2), 107-122. https://doi.org/10.21632/irjbs.8.2.107-122

Schaufeli, W. B. (2012). Work engagement. What do we know and where do we go? Romanian Journal of Applied Psychology, 14(1), 3-10.

Schaufeli, W. B. (2013). What is engagement? In C. Truss, K. Alfes, R. Delbridge, A. Shantz, \& E. Soane (Eds.), Employee engagement in theory and practice. London: Routledege.

Schaufeli, W. B., \& Bakker, A. B. (2003). UWES Utrecht Work Engagement Scale: test manual. Utrecht: Department of Psychology, Utrecht University.

Schaufeli, W. B., \& Bakker, A. B. (2004). Job demands, job resources, and their relationship with burnout and engagement: A multi-sample study. Journal of Organizational Behavior, 25(3), 293-315. https://doi.org/10.1002/job.248

Schaufeli, W. B., Bakker, A. B., \& Salanova, M. (2006). The measurement of work engagement with a short questionnaire: A cross-national study. Educational and Psychological Measurement, 66(4), 701-716. https://doi.org/10.1177/0013164405282471

Schaufeli, W. B., Salanova, M., González-romá, V., \& Bakker, A. B. (2002). The measurement of engagement and burnout: A two sample confirmatory factor analytic approach. Journal of Happiness Studies, 3(1), 71-92. https://doi.org/10.1023/A:1015630930326

Scheier, M. F., Carver, C. S., \& Bridges, M. W. (1994). Distinguishing optimism from neuroticism (and trait anxiety, self-mastery, and self-esteem): A reevaluation of the Life Orientation Test. Journal of Personality and Social Psychology, 67(6), 1063-1078. https://doi.org/10.1037/00223514.67.6.1063

Sharma, A., Goel, A., \& Sengupta, S. (2017). How does Work Engagement vary with Employee Demography? - Revelations from the Indian IT industry. Procedia Computer Science, 122, 146153. https://doi.org/10.1016/j.procs.2017.11.353

Sholihin, M., \& Ratmono, D. (2014). Analisis SEM-PLS dengan WarpPLS 3.0 untuk hubungan nonlinier dalam penelitian sosial dan bisnis. Yogyakarta: Andi Publisher.

Snyder, C. R., \& Lopez, S. J. (2002). Handbook of positive psychology. In Handbook of Positive Psychology. https://doi.org/10.1093/oxfordhb/9780195187243.001.0001

Sparr, J. L., \& Sonnentag, S. (2008). Fairness perceptions of supervisor feedback, LMX, and employee well-being at work. European Journal of Work and Organizational Psychology, 17(2), 198-225. https://doi.org/10.1080/13594320701743590 
Sunjoyo, D. (2013). Aplikasi SPSS untuk smart riset. Bandung: Alfabeta.

Taghipour, A., \& Dezfuli, Z. K. (2013). Designing and testing a model of antecedents of work engagement. Procedia - Social and Behavioral Sciences, 84, 149-154. https://doi.org/10.1016/ j.sbspro.2013.06.526

Tesi, A., Aiello, A., \& Giannetti, E. (2018). The work-related well-being of social workers: Framing job demands, psychological well-being, and work engagement. Journal of Social Work, 19(1), 121141. https://doi.org/10.1177/1468017318757397

Trinchero, E., Borgonovi, E., \& Farr-Wharton, B. (2014). Leader-member exchange, affective commitment, engagement, wellbeing, and intention to leave: Public versus private sector Italian nurses. Public Money and Management, 34(6), 381-388. https://doi.org/ 10.1080/09540962.2014.962361

Vijayakumari, K. *, \& Vrinda. (2016). Work engagement in relation to psychological well-being and motivation at work. Guru Journal of Behavioral and Social Sciences, 4(3-4), 589-594. Retrieved from www.gjbss.org

Wright, T. A., \& Bonett, D. G. (2007). Job satisfaction and psychological well-being as nonadditive predictors of workplace turnover. Journal of Management, 33(2), 141-160. https://doi.org/ $10.1177 / 0149206306297582$

Wulandari, S. M., \& Ratnaningsih, I. Z. (2016). Hubungan antara Leader Member Exchange (LMX) dengan work engagement pada perawat instalasi rawat inap di RSJD Dr. Amino Gondohutomo Semarang. Jurnal Empati, 5(4), 721-726. Retrieved from https://ejournal3.undip.ac.id/ index.php/empati/article/view/15452 